

\title{
Implementasi Program Power Point Ispring Dalam Meningkatkan Pemahaman Konsep Gerak Lurus dan Motivasi Belajar Siswa di SMPN 2 Tarongong Kidul Garut
}

\author{
Irwanto $^{\bowtie}$, Tika Nurmalatika
}

Jurusan Pendidikan Vokasional Teknik Elektro, Fakultas Keguruan dan Ilmu Pendidikan, Universitas Sultan Agung Tirtayasa, Indonesia

\section{Info Artikel}

Sejarah Artikel:

Diterima: Agustus 2019

Direvisi: Desember 2019

Disetujui: Desember 2019

Keywords:

Power Point Ispring,

Pemahaman, Motivasi

Belajar

\begin{abstract}
Abstrak
Adapun tujuan penelitian ini adalah untuk mengetahui penggunaan program power point ispring terhadap peningkatan pemahaman konsep gerak lurus dan motivasi belajar siswa di kelas VII SMPN 2 Tarogong Kidul Garut. ISpring Presenter merupakan salah satu tool yang mengubah file presentasi menjadi bentuk flash dan bentuk SCORM / AICC, yaitu bentuk yang biasa digunakan dalam pembelajaran dengan e-learning LMS (Learning management System). Perangkat lunak Ispring tersedia dalam versi free (gratis) dan berbaya Metode penelitian yang digunakan adalah metode penelitian eksperimen menggunakan bentuk desain eksperimen type Quasi eksperimental design dengan bentuk nonequivalent control group design". Populasi dalam penelitian ini adalah seluruh kelas VII siswa SMPN 2 Tarogong Kidul Garut sebanyak 9 kelas. Pengambilan sampel dilakukan dengan cara acak kelas yaitu kelas VIIG sebanyak 36 orang sebagai kelas eksperimen dan kelas VIIK sebanyak 33 orang sebagai kelas kontrol. Teknik pengumpulan data yang digunakan adalah obsrvasi, angket dan tes. Hasil penelitian, diperoleh adalah (1) adanya peningkatan pemahaman konsep gerak lurus pada siswa yang pembelajarannya menggunakan program power point Ispring termasuk dalam kategori tinggi. Sementara pada siswa yang pembelajarannya tidak menggunakan program power point ispring tidak mengalami peningkatan signifikan yaitu kategori rendah (2) adanya peningkatan motivasi belajar pada siswa yang pembelajarannya menggunakan program Power point Ispring termasuk dalam kategori tinggi sedangkan peningkatan motivasi belajar pada siswa yang pembelajarannya tidak menggunakan Power point Ispring tergolong kategori rendah.
\end{abstract}

\begin{abstract}
The purpose of this study was to determine the use of ispring power point programs to increase understanding of the concept of straight motion and student motivation in class VII at SMPN 2 Tarogong Kidul Garut. ISpring Presenter is a tool that converts presentation files into flash and SCORM / AICC forms, which are forms commonly used in learning with e-learning LMS (Learning management System). The Ispring software is available in a free and free version. The research method used is an experimental research method using the experimental design type Quasi experimental design with the form of nonequivalent control group design. The population in this study were all grade VII students of SMPN 2 Tarogong Kidul Garut as many as 9 classes. Sampling was done by random class namely 36 people in class VIIG as an experimental class and 33 people in class VIIK as a control class. Data collection techniques used were observation, questionnaires and tests. The results of the study obtained are (1) an increase in understanding the concept of straight motion in students whose learning uses the Ispring power point program is included in the high category. While students whose learning did not use the Ispring Power Point program did not experience a significant increase in the low category (2) there was an increase in learning motivation in students whose learning using the Ispring Power Point program was included in the high category while the increase in learning motivation in students whose learning did not use Power Points Ispring is in the low category.
\end{abstract}

(C) 2019 Universitas Negeri Semarang 


\section{PENDAHULUAN}

Pendidikan adalah proses sosial dalam memanusiakan manusia melalui pembelajaran yang dilakukan secara sadar, baik secara terencana maupun tidak (Suprihatiningrum, 2016). Pendidikan dapat dilihat dalam dua sisi yaitu pendidikan sebagai praktik dan pendidikan sebagai teori. Pendidikan sebagai praktik yakni seperangkat kegiatan atau aktivitas yang dapat diamati dan disadari dengan tujuan untuk membantu peserta didik agar memperoleh perubahan perilaku. Sementara pendidikan sebagai teori yaitu seperangkat pengetahuan yang telah tersusun secara sistematis yang berfungsi untuk menjelaskan, menggambarkan, meramalkan dan mengontrol berbagai gejala dan peristiwa pendidikan, baik yang bersumber dari pengalaman-pengalaman pendidikan maupun hasil perenungan-perenungan yang mendalam untuk melihat makna pendidikan dalam konteks yang lebih luas.

Teknologi pembelajaran telah berkembang sebagai teori dan praktik dimana proses, sumber dan sistem belajar pada manusia baik perseorangan maupun dalam suatu ikatan organisasi dapat dirancang, dikembangkan, dimanfaatkan, dikelola dan dievaluasi. Pada hakekatnya teknologi pembelajaran adalah suatu disiplin ilmu yang berkepentingan dengan pemecahan masalah belajar dengan berlandaskan pada serangkaian prinsip dan menggunakan berbagai macam pendekatan atau teori komunikasi dan teknologi komunikasi (Warsita, 2008).

Adapun tujuan dari penelitian ini adalah untuk mengetahui penggunaan Program PowerPoint ISpring terhadap peningkatan pemahaman konsep gerak lurus dan motivasi belajar siswa di kelas VII SMPN 2 Tarogong Kidul Garut. Dalam mencapai tujuan pendidikan guru merupakan komponen yang menentukan, terlebih saat proses pembelajaran bagi peserta didik pendidikan dasar, karena mereka masih memerlukan bimbingan dan bantuan guru. Guru tidak hanya berperan sebagai model atau teladan tetapi sebagai pengelola pembelajaran ditentukan oleh kualitas atau kemampuan guru. Guru sebagai tenaga professional harus terus melakukan perubahan-perubahan atau sedikitnya penyesuaian dalam paradigma strategi, pendekatan, dan teknologi pembelajaran, jika tidak, maka tenaga professional ini akan kehilangan makna kehadiran dan proses pembelajaran.

Banyak metode atau cara mengajar yang dapat digunakan dalam proses belajar mengajar untuk mencapai tujuan pembelajaran, tetapi tidak semua metode tersebut cocok untuk semua materi yang diajarkan. Dalam memilih dan menggunakan metode mengajar harus disesuaikan dengan tujuan, materi, sarana, karakteristik siswa dan evaluasi. Khusus mengenai metode mengajar di kelas, selain faktor tujuan, faktor murid, situasi dan faktor guru pun ikut menentukan efektif tidaknya sebuah metode. Selanjutnya, pertimbangan pokok dalam memilih dan menentukan metode mengajar terletak pada keefektifan proses belajar mengajar. Jadi, metode mengajar yang digunakan pada dasarnya berfungsi sebagai pembimbing agar siswa belajar, untuk itu adalah bijaksana apabila seorang guru memahami metode mengajar (Warsita, 2008).

Tingkat pendidikan yang tinggi bergantung pada mutu pendidikan yang mana berkaitan erat dengan proses belajar mengajar. Dewasa ini para ahli berusaha untuk meningkatkan proses belajar mengajar itu menjadi suatu ilmu atau teknologi yang dapat dikenal dan dikuasai langkahlangkahnya. Disinilah peran teknologi pendidikan sangat diperlukan. Teknologi pendidikan merupakan kajian dan praktek untuk membantu proses belajar dan meningkatkan kinerja dengan membuat, menggunakan dan mengelola proses dan sumber teknologi yang memadai (Hernawati, 2011).

Surya (2013) menyatakan bahwa secara umum teori adalah seperangkat prinsip yang sistematis dan berbasis penalaran sebagai kerangka kerja konseptual dan telah teruji secara empiris dalam memberikan penjelasan terhadap suatu fenomena tertentu. Dengan rumusan ini, maka yang dimaksud dengan teori pembelajaran adalah seperangkat prinsip yang sistematis dan berbasis penalaran sebagai kerangka kerja konseptual dan telah teruji secara empiris dalam memberikan penjelasan dan pemecahan masalah fenomena pembelajaran.

Microsoft PowerPoint merupakan sebuah program komputer untuk presentasi yang dikembangkan oleh Microsoft. Adapun pengertian Powerpoint disini adalah Microsoft PowerPoint adalah program aplikasi untuk membuat atau mengelola data presentasi. Data presentasi yang dibuat dapat beruoa teks, tabel gambar, bagan organisasi, dan sebagainya (Gumawang, 2005). Power Point berjalan diatas komputer PC berbasis operasi Microsoft Windows dan Apple Macintosh yang menggunakan sistem operasi Apple Mac OS, meskipun pada awalnya aplikasi ini berjalan di atas system operasi Xenix. Aplikasi ini sangat berguna apalagi oleh kalangan perkantoran dan pebisnis, para pendidik siswa dan trainer. Dimulai dari versi Microsoft Office System 2007, Microsoft mengganti nama menjadi Microsoft Office PowerPoint. Aplikasi Microsoft PowerPoint pertama kali dikembangkan oleh Bob 
Gaskins dan Dennis Austin sebagai presenter uuntuk perusahaan bernama Forenthought Ich yang kemudian mereka ubah namanya menjadi Powerpoint.

Operasi dalam PowerPoint seperti hal nya perangkat lunak pengolah presentasi lainnya objek, teks, grafik, video, suara dan objek-objek lainnya diposisikan dalam beberapa halaman individual yang disebut "slide". Istilah slide dalam PowerPoint adalah memiliki analogi yang sama dengan slide dalam proyektor biasa yang telah kuno akibat munculnya perangkat baru komputer yang mampu mengolah presentasi semacam PowerPoint dan Impress. Setiap slide dapat dicetak atau ditampilkan dalam layar dan dapat dinavigasikan melalui perintah dari presenter.

Dengan PowerPoint sebenarnya siapapun dapat memanfaatkannya, sepanjang ditujukan untuk menyampaikan informasi. Pelajar menggunakan PowerPoint untuk menyajikan pekerjaan rumah yang perlu disampaikan kepada bapak/ibu guru dan rekan-rekan sekelas. Guru atau dosen bisa menyajikan materi kuliah di kelas. Informasi di tempat umumpun dapat disampaikan dengan menggunakan PowerPoint. Dalam hal ini, pemakai dapat meng-klik tombol-tombol secara interaktif untuk mendapatkan informasi yang dikehendaki.

Kemajuan teknologi pembelajaran banyak menghasilkan produk yang bermanfaat bagi penunjang keberhasilan ketercapaian tujuan pembelajaran (Iriyanto, 2008). Salah satu produk teknologi pembelajaran yaitu Microsoft office PowerPoint yang telah diinsert menu ISpring Presenter. ISpring Presenter merupakan salah satu tool yang mengubah file presentasi menjadi bentuk flash dan bentuk SCORM/AICC, yaitu bentuk yang biasa digunakan dalam pembelajaran dengan e-learning LMS (Learning management System).

Dengan menggunakan multimedia PowerPoint Ispring diharapkan siswa lebih termotivasi dan mampu meningkatkan prestasi belajarnya. Dengan demikian maka penggunakan multimedia PowerPoint Ispring diyakini bisa membuat siswa antusias dalam belajar di kelas maupun belajar di rumah. Dengan adanya multimedia tersebut diharapkan guru juga merasa terbantu dalam meminimalisasi tenaga dalam peragaan praktik fisika.

Kemajuan teknologi pembelajaran banyak menghasilkan produk yang bermanfaat bagi penunjang keberhasilan ketercapaian tujuan pembelajaran. Salah satu produk teknologi pembelajaran yaitu Microsoft office PowerPoint yang telah diinsert menu ISpring Presenter. Dengan menggunakan multimedia PowerPoint Ispring diharapkan siswa lebih termotivasi dan mampu meningkatkan prestasi belajarnya. Dengan demikian maka penggunakan multimedia PowerPoint Ispring diyakini bisa membuat siswa antusias dalam belajar di kelas maupun belajar di rumah. Dengan adanya multimedia tersebut diharapkan guru juga merasa terbantu dalam meminimalisasi tenaga dalam peragaan praktik sains.

Dalam hal ini belum bisa dilaksanakan secara baik dan benar karena berdasarkan pengamatan peneliti di kelas VII SMPN 2 Tarogong Kidul Garut, ada beberapa temuan masalah yang dihadapi dalam pelaksanaan metode presentasi seperti halnya program Power Point ini, diantaranya: (a) belum optimalnya dalam penggunaan multimedia pembelajaran, hal ini terbukti dari kurangnya sarana dan prasarana. (b) belum dipahaminya penggunaan multimedia Powerpoint ISpring sehingga dalam penampilannya kurang bervariasi, sehingga membuat siswa kurang tertarik dalam mengikuti proses pembelajaran dan (c) pemahaman belajar siswa masih kurang hal ini dapat dilhat dari pencapaian nilai KKM Mata Pelajaran Fisika pada materi gerak lurus yang masih jauh dari yang diharapkan. Oleh sebab itu, maka untuk lebih mengoptimalkan pembelajaran, khususnya dalam pelajaran praktik sains dalam meningkatkan pemahaman belajar siswa maka penulis mencoba melakukan pembelajaran dengan menggunakan perangkat multimedia yang nantinya diharapkan dapat lebih memotivasi cara belajar siswa dan juga mempermudah siswa untuk lebih mudah mengingat, melakukan bahkan memahami pelajaran praktik Sains tersebut khususnya pada materi gerak lurus. Peneliti mencoba mengkaji lebih dalam perihal permasalahan di atas dan mengambil judul: Penggunaan Program PowerPoint ISpring Dalam Meningkatkan Pemahaman Konsep Gerak Lurus dan Motivasi Belajar Siswa di SMPN 2 Tarogong Kidul Garut.

\section{METODE PENELITIAN}

Metode yang digunakan dalam penelitian ini adalah metode penelitian eksperimen, yaitu metode yang digunakan untuk mencari pengaruh perlakuan tertentu terhadap yang lain dalam kondisi yang terkendalikan. Menurut Darmawan (2013) menyatakan bahwa Penelitian eksperimen menggunakan suatu percobaan yang dirancang secara khusus guna membangkitkan data yang diperlukan untuk menjawab pertanyaan penelitian (Sugiyono, 2016).

Desain penelitian eksperimen yang digunakan yaitu desain eksperimen Quasi Eksperimental Design dengan bentuk Nonequivalent Control Group Design. Dalam penelitian ini Populasi dalam penelitian ini adalah seluruh 
kelas VII siswa SMPN 2 Tarogong Kidul Garut sebanyak 9 kelas dengan jumlah siswa 324 Orang, Sampel dalam penelitian ini adalah kelas VIIG sebanyak 36 orang sebagai kelas eksperimen dan kelas VIIK sebanyak 36 orang sebagai kelas kontrol. Hal ini dilakukan karena banyak kelas dan sampel didasarkan pada alasan memiliki karakteristik yang homogen.

Dalam penelitian ini menggunakan iSpring Powerpoint, seperti pada Gambar 1 dibawah ini.

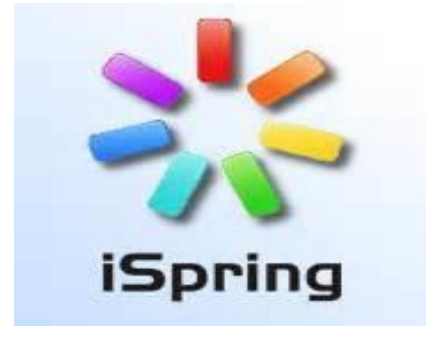

Gambar 1. Tampilan awal program iSpring

ISpring Presenter merupakan salah satu tool yang mengubah file presentasi yang kompatibel dengan Power Point untuk menjadikan bentuk flash. Perangkat lunak Ispring tersedia dalam versi free (gratis) dan pro. Dalam penelitian ini penulis menentukan variabel independen dan variabel dependen. Terdapat tiga variabel untuk penelitian ini yakni satu variabel independen dan dua variabel dependen. Variabel independen dalam penelitian ini adalah penggunaan program Powerpoint Ispring (X), sedangkan variabel dependen yaitu pemahaman (Y1) dan motivasi (Y2). Hubungan diantara variabel-variabel tersebut dapat di Gambarkan sebagai berikut:



Gambar 2. Hubungan variabel penelitian

Dalam penelitian ini metode penelitian eksperimen yang digunakan yaitu desain eksperimen Quasi Eksperimental Design dengan bentuk Nonequivalent Control Group Design. Proses tersebut dapat dianalogikan seperti Tabel 1 di bawah ini.
Tabel 1. Desain exsperimen

\begin{tabular}{llll}
\hline Kelompok & Pretest & Treatment & Posttest \\
\hline Eksperimen & $\mathrm{T} 1$ & $\mathrm{X} 1$ & $\mathrm{~T} 2$ \\
Kontrol & $\mathrm{T} 1$ & $\mathrm{X} 2$ & $\mathrm{~T} 2$ \\
\hline Keterangan: & & \\
$\mathrm{T} 1=$ Pretest & & \\
$\mathrm{T} 2=$ Posttest & \\
$\mathrm{X} 1=$ Perlakuan dengan menggunakan media \\
$\quad$ Powerpoint Ispring \\
$\mathrm{X} 2 \quad \begin{array}{l}\text { Perlakuan dengan tanpa menggunakan media } \\
\text { Powerpoint Ispring }\end{array}$
\end{tabular}

Sugiyono (2012) mengatakan instrumen dikatakan valid berarti dapat digunakan untuk mengukur apa yang seharusnya diukur. Untuk koefisien validitas digunakan rumus korelasi Pearson Product Moment berikut:

$$
\mathrm{r}_{\mathrm{XY}}=\frac{N \Sigma x y-(\Sigma x) \cdot(\Sigma y)}{\sqrt{\left[x^{2}-(\Sigma x)^{2}\right] \cdot\left[N \Sigma Y^{2}-(\Sigma Y)^{2}\right]}}
$$

$\mathrm{rXY}=$ koefisien korelasi antara variabel $\mathrm{X}$ dan variabel $\mathrm{Y}$

$\mathrm{N}=$ banyaknya responden

$\mathrm{X}=$ skor tiap item butir soal

$\mathrm{Y}=$ skor total butir soal

Pengujian reliabilitas bertujuan untuk melihat ketetapan atau keajegan alat ukur yang digunakan. Untuk mengukur reliabilitas butir soal, digunakan rumus Cronbach Alpha (Sundayana, 2010).

$$
\begin{aligned}
& r_{11}=\left(\frac{n}{n-1}\right)\left(1-\frac{\Sigma s_{1}^{2}}{s_{1}^{2}}\right) \\
& r 11 \quad=\text { Realibitas instrumen } \\
& n \quad=\text { banyaknya butir pertanyaan } \\
& \sum s_{1}^{2} \quad=\text { jumlah varians item } \\
& s_{1}^{2} \quad=\text { varians total }
\end{aligned}
$$

Untuk menginterpretasikan derajat reliabilitas ini digunakan tolak ukur dari Guilford (dalam Sundayana, 2010) seperti pada Tabel 2 di bawah ini.

Tabel 2. Klasifikasi Koefisien Reliabilitas

\begin{tabular}{cl}
\hline Koefisien Reliabilitas $(\mathrm{r})$ & Interpretasi \\
\hline $0,00 \leq \mathrm{r}<0,20$ & Kecil \\
$0,20 \leq \mathrm{r}<0,40$ & Rendah \\
$0,40 \leq \mathrm{r}<0,60$ & Sedang/Cukup \\
$0,60 \leq \mathrm{r}<0,80$ & Tinggi \\
$0,80 \leq \mathrm{r}<1,00$ & Sangat Tinggi \\
\hline
\end{tabular}


Teknik pengumpulan data merupakan teknik atau cara yang dilakukan untuk mengumpulkan data. Metode menunjuk suatu cara sehingga dapat diperlihatkan penggunaannya melalui angket, wawancara, pengamatan, tes, doumentasi dan sebagainya. Berdasarkan sumbernya, data dibagi menjadi data primer, yaitu data yang diusahakan/didapat oleh peneliti, dan data sekunder yaitu data yang didapat dari orang atau instansi lain.

Perhitungan skor peningkatan kemampuan pemahaman konsep dan motivasi belajar, dilakukan dengan menggunakan gain ternormalisasi. Besarnya peningkatan kemampuan pemahaman konsep dan motivasi belajar antara sebelum dan sesudah pembelajaran dihitung dengan rumus gain ternormalisasi (normalized gain) yang dikembangkan oleh Hake dalam Sundayana, 2010 sebagai berikut:

Gain ternormalisasi $(\mathrm{g})=\frac{\text { skor postes }- \text { skor pretes }}{\text { skor ideal }- \text { skor pretes }}$

Sundayana (2010) menginterpretasikan skor gain ternormalisasi (g) seperti pada Tabel 3 berikut ini.

Tabel 3. Interpretasi Gain Ternormalisasi yang Dimodifikasi

\begin{tabular}{cl}
\hline Koefisien Reliabilitas $(\mathrm{r})$ & Interpretasi \\
\hline$-1,00 \leq \mathrm{g}<0,00$ & Terjadi penurunan \\
$\mathrm{g}=0,00$ & Tidak terjadi \\
& peningkatan \\
$0,00<\mathrm{g}<0,30$ & Rendah \\
$0,30 \leq \mathrm{r}<0,70$ & Sedang \\
$0,70 \leq \mathrm{r} \leq 1,00$ & Tinggi \\
\hline
\end{tabular}

Normalitas sebaran data menjadi syarat untuk menentukan jenis statistik apa yang dipakai dalam penganalisaan selanjutnya. Dalam penelitian ini, ukuran sampel kelas eksperimen dan kelas kontrol masing-masing sebanyak 36 dan 33 siswa, sehingga untuk uji normalitas data diuji dengan menggunakan Uji Shapiro-Wilk. Dari hasil uji normalitas ternyata sebaran data tidak berdistribusi normal, sehingga untuk pengujian dua rata-rata penulis gunakan statistik non parametrik, yaitu uji Mann Whitney. Prosedur penelitian ini, penulis sajikan dalam Gambar 3 berikut ini.



Gambar 3. Prosedur penelitian

Ispring Presenter secara mudah dapat diintegrasikan dalam Microsoft Power Point sehingga tidak membutuhkan keahlian khusus. Beberapa fitur Ispring Presenter adalah: iSpring Presenter bekerja sebagai add-ins PowerPoint, untuk menjadikan file PowerPoint lebih menarik dan interaktif berbasis Flash dan dapat dibuka di hampir setiap komputer atau platform. Dikembangkan untuk mendukung e-learning. iSpring Presenter dapat menyisipkan berbagai bentuk media, sehingga media pembelajaran yang dihasilkan akan lebih menarik, diantaranya adalah dapat merekam dan sinkronisasi video presenter, menambahkan Flash dan video YouTube, mengimpor atau merekam audio, menambahkan informasi pembuat presentasi dan logo perusahaan, serta membuat navigasi dan desain yang unik (pro).

Mudah didistribusikan dalam format flash, yang dapat digunakan dimanapun dan dioptimalkan untuk web. Membuat kuis dengan berbagai jenis pertanyaan/soal yaitu: True/False, Multiple Choice, Multiple response, Type In, Matching, Sequence, numeric, Fill in the Blank, Multiple Choice Text (pro), seperti pada Gambar 4 di bawah ini. 


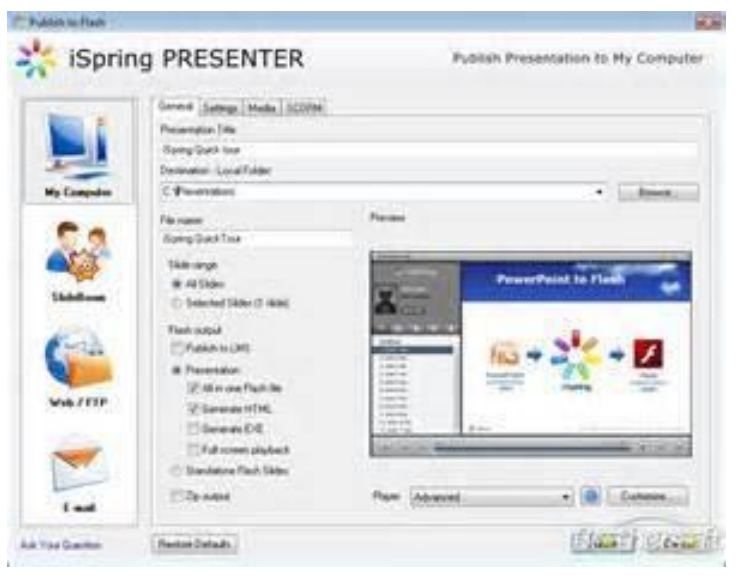

Gambar 4. Ispring presenter

Cara menggunaan iSpring dalam aplikasi Power Point: Dengan menginstall program iSppring, aplikasi ini dapat di download secara gratis dengan kisaran file $24 \mathrm{Mb}$ di http://www.ispringfree.com/download.html. Buka file presentasi yang telah dibuat di Power Point, jika animasi Anda ingin dijalankan dengan automatis (tanpa menggunakan klik atau enter) maka sebaiknya pada efek animasinya (start) tidak menggunakan on click tetapi lebih disarankan memakai efek animasi-start: after previous, sehingga presentasi dapat berjalan sendiri tanda di enter atau di klik.

- Pastikan bahwa slide animasi yang akan diubah sudah final sesuai keinginan, dengan cara menjalankan (slide show atau tekan F5). Jika versi 2010, maka pilih iSpring (pada addres bar) lalu klik Publish, maka muncul kotak dialog Presentation title $=$ silahkan ganti nama file yang diinginkan) Slide range $=$ klik All slides untuk di Publish Options = jangan beri tanda checklist, seperti pada Gambar 5 di bawah ini.

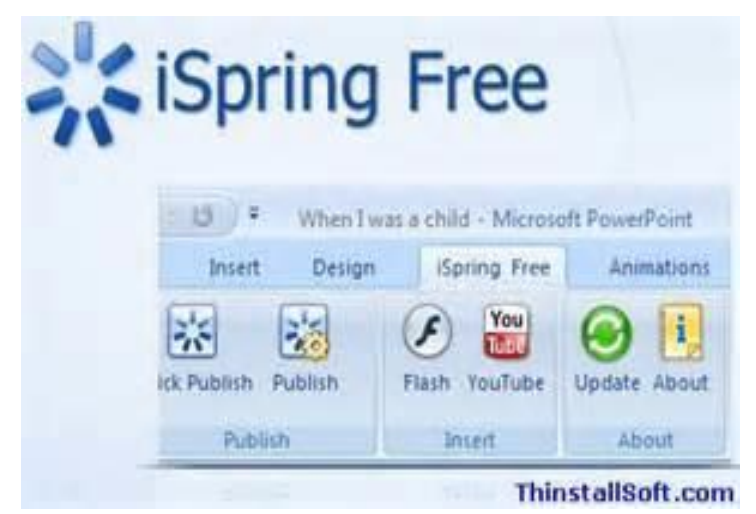

Gambar 5. Slide animasi

\section{HASIL DAN PEMBAHASAN}

Deskripsi hasil penelitian mengenai Peningkatan pemahaman konsep gerak lurus.

a. Kelas Eksperimen

Dari sampel penelitian sebanyak 36 siswa, sebelum dilakukan penelitian, penulis melakukan tes awal (pretes). Kemudian dilakukan pembelajaran menggunakan program powerpoint model Ispring dilanjutkan dengan tes akhir (postes). Setelah data pretes dan data postes terkumpul, dilakukan perhitungan peningkatan pemahaman konsep Gerak Lurus dengan menggunakan gain ternormalisasi. Dari sebaran data tersebut, maka langkah selanjutnya dibuat deskripsi data berupa nilai rata-rata (mean), modus (mode), simpangan baku, nilai minimum dan nilai maksimum. Hasil pengolahan data disajikan pada Tabel 4 berikut:

Tabel 4. Deskripsi Pemahaman Konsep Gerak Lurus Kelas Eksperimen

\begin{tabular}{llll}
\hline & Pretes & Postes & Gain \\
\hline $\mathrm{N} \quad$ Valid & 36 & 36 & 36 \\
Mean & 27,64 & 52,61 & 0,5272 \\
Mode & 19 & 58 & 0,45 \\
Std.Deviation & 12,187 & 9,219 & 0,12921 \\
Range & 50 & 38 & 0,42 \\
Minimum & 5 & 30 & 0,33 \\
Maximum & 55 & 68 & 0,75 \\
\hline
\end{tabular}

Dari Tabel 4 diketahui bahwa rata-rata dari hasil belajar sebelum dilakukan penelitian sebesar 27,64 dan setelah pembelajaran menggunakan program powerpoint model Ispring menjadi 52,61. Dari hal tersebut secara deskriptif mengalami peningkatan belajar (gain) sebesar 0,5272. Merujuk pada interpretasi gain, peningkatan pemahaman konsep gerak lurus pada kelas eksperimen tersebut termasuk dalam kategori sedang.

\section{b. Kelas Kontrol}

Seperti halnya kelas eksperimen, pada kelas kontrol dari sampel penelitian sebanyak 33 siswa, sebelum dilakukan penelitian, penulis melakukan tes awal (pretes). Kemudian dilakukan pembelajaran menggunakan model konvensional dilanjutkan dengan tes akhir (postes). Setelah data pretes dan data postes terkumpul, dilakukan perhitungan peningkatan hasil belajar menggunakan gain ternormalisasi. Dari sebaran data tersebut, maka langkah selanjutnya dibuat deskripsi data berupa nilai rata-rata (mean), modus (mode) simpangan baku, nilai minimum dan nilai maksimum. Hasil pengolahan data disajikan pada Tabel 5 berikut: 
Tabel 5. Deskripsi Pemahaman Konsep Gerak Lurus Kelas Control

\begin{tabular}{llll}
\multicolumn{4}{c}{ Lurus Kelas Control } \\
\hline $\mathrm{N} \quad$ Palid & 33 & 33 & Gain \\
Mean & 27,52 & 42,12 & 0,3097 \\
Mode & $6^{\mathrm{a}}$ & $49^{\mathrm{a}}$ & $0,22^{\mathrm{a}}$ \\
Std.Deviation & 12,787 & 10,562 & 0,9204 \\
Range & 44 & 36 & 0,43 \\
Minimum & 6 & 21 & 0,13 \\
Maximum & 50 & 57 & 0,56 \\
\hline
\end{tabular}

Dari Tabel 5 diketahui bahwa rata-rata dari hasil belajar sebelum dilakukan penelitian sebesar 27,52 dan setelah pembelajaran menggunakan metode konvensional menjadi 42,12. Dari hal tersebut secara deskriptif mengalami peningkatan (gain) sebesar 0,3097 sehingga tergolong kategori sedang. Adapun secara lengkap data peningkatan pemahaman konsep gerak lurus dari 33 siswa.

Uji Perbedaan peningkatan pemahaman konsep gerak lurus antara siswa yang pembelajarannya menggunakan Program PowerPoint ISpring dengan siswa yang pembelajarannya tidak menggunakan Program PowerPoint ISpring

Sebelum dilakukan pengujian hipotesis, apakah ada perbedaan pemahaman konsep Gerak Lurus antara siswa yang pembelajarannya menggunakan program Powerpoint Ispring dengan siswa yang pembelajarannya tidak menggunakan program Powerpoint Ispring, maka dilakukan uji sebaran normalitas data. Pengujian sebaran normalitas data pemahaman konsep Gerak Lurus dari kedua kelompok diperoleh hasil pada Tabel 6 di bawah ini.

Tabel 6. Uji Sebaran Normalitas Data Peningkatan Pemahaman Konsep Gerak Lurus

\begin{tabular}{llll}
\hline & \multicolumn{3}{c}{ Shapiro-Wilk } \\
\cline { 2 - 4 } & Statistic & Df & Sig. \\
\hline $\begin{array}{l}\text { Gain_pemahaman } \\
\text { eksperimen }\end{array}$ & 0,901 & 36 & 0,04 \\
$\begin{array}{l}\text { Gain_pemahaman } \\
\text { control }\end{array}$ & 0,962 & 33 & 0,295 \\
\hline
\end{tabular}

Kriteria sebaran data berdistribusi normal jika nilai Sig. lebih besar dari taraf signifikansi yang digunakan $(\alpha)$. Dalam penelitian ini $\alpha$ yang digunakan sebesar 0,05 ; sebaran data peningkatan pemahaman konsep Gerak Lurus /gain kelas eksperimen mempunyai nilai Sig = 0,004 dan untuk sebaran data peningkatan pemahaman konsep Gerak Lurus kelas kontrol mempunyai nilai Sig $=0,295$; sehingga sebaran data peningkatan pemahaman konsep pada kelas eksperimen tidak berdistribusi normal, sedangkan pada kelas control berdistribusi normal.

Pengujian selanjutnya, karena sebaran data pemahaman konsep Gerak Lurus tersebut terdapat sebaran yang tidak berdistribusi normal, maka digunakan statistika non parametrik, dalam hal ini penulis gunakan uji Mann Whitney.

Adapun rumusan hipotesisnya penulis sajikan sebagai berikut:

Ho: Tidak terdapat perbedaan peningkatan pemahaman konsep Gerak Lurus, antara siswa yang pembelajarannya menggunakan program Powerpoint Ispring dengan siswa yang pembelajarannya tidak menggunakan program Powerpoint Ispring

Ha: Terdapat perbedaan peningkatan pemahaman konsep Gerak Lurus, antara siswa yang pembelajarannya menggunakan program Powerpoint Ispring dengan siswa yang pembelajarannya tidak menggunakan program Powerpoint Ispring.

Dari hasil pengujian, diperoleh hasil Tabel 7 sebagai berikut.

Tabel 7. Uji Perbedaan Pemahaman Konsep

\begin{tabular}{lllll}
\multicolumn{6}{c}{ Gerak Lurus } \\
\hline & Kelas & $\mathrm{N}$ & $\begin{array}{l}\text { Mean } \\
\text { Rank }\end{array}$ & $\begin{array}{l}\text { Sum of } \\
\text { Ranks }\end{array}$ \\
\hline gain_pem & Eksperimen & 36 & 49,14 & 1769,00 \\
ahaman & Kontrol & 33 & 19,58 & 646,00 \\
& Total & 69 & & \\
\hline
\end{tabular}

\begin{tabular}{ll}
\multicolumn{2}{c}{ Test $^{\text {Statistics }}{ }^{a}$} \\
\hline Gain_pemahaman \\
\hline Mann-Whitney U & 85,000 \\
Z & $-6,118$ \\
Asymp. Sig. (2-tailed) & 0,000 \\
\hline
\end{tabular}
a. Grouping Variable: Kelas

Dari pengujian tersebut, diperoleh ratarata ranking/mean rank dari kelas eksperimen dan kelas kontrol berturut-turut 49,14 dan 19,58. Hasil pengujian dengan uji Mann Whitney U diperoleh nilai sebesar 85,000 dengan nilai $\mathrm{z}$ sebesar -6,118 serta nilai Asymp. Sig. (2-tailed) sebesar 0,000. Adapun kriteria pengujian hipotesisnya adalah, jika nilai Asymp. Sig. (2tailed) lebih kecil dari $\alpha$ maka Ha diterima atau Ho ditolak. Karena pada pengujian ini nilai Asymp. Sig. (2-tailed) $=0,000$ lebih kecil dari $\alpha=$ 0,05 maka $\mathrm{Ha}$ diterima, sehingga dapat disimpulkan bahwa: Terdapat perbedaan peningkatan pemahaman konsep Gerak Lurus, antara siswa yang yang pembelajarannya 
menggunakan program Powerpoint Ispring dengan siswa yang pembelajarannya tidak menggunakan program Powerpoint Ispring". Dalam hal ini peningkatan pemahaman siswa yang pembelajarannya menggunakan program Powerpoint Ispring lebih baik daripada pemahaman siswa yang pembelajarannya tidak menggunakan program Powerpoint Ispring

Uji perbedaan peningkatan motivasi belajar antara siswa yang pembelajarannya menggunakan Program PowerPoint ISpring dengan siswa yang pembelajarannya tidak menggunakan Program PowerPoint Ispring

Sebelum dilakukan pengujian hipotesis, apakah ada perbedaan peningkatan motivasi belajar siswa antara siswa yang pembelajarannya menggunakan program Powerpoint Ispring dengan siswa yang pembelajarannya tidak menggunakan program Powerpoint Ispring, maka dilakukan uji sebaran normalitas data. Pengujian sebaran normalitas data motivasi belajar siswa dari kedua kelompok diperoleh hasil seperti pada Tabel 8 sebagai berikut:

Tabel 8. Uji Sebaran Normalitas Data Peningkatan Motivasi Belajar Siswa

\begin{tabular}{llll}
\hline & \multicolumn{3}{c}{ Shapiro-Wilk } \\
\cline { 2 - 4 } & Statistic & Df & Sig. \\
\hline $\begin{array}{l}\text { Gain_motivasi } \\
\text { eksperimen }\end{array}$ & 0,828 & 36 & 0,000 \\
$\begin{array}{l}\text { Gain_motivasi } \\
\text { control }\end{array}$ & 0,969 & 33 & 0,450 \\
\hline
\end{tabular}

Kriteria sebaran data berdistribusi normal jika nilai Sig. lebih besar dari taraf signifikansi yang digunakan $(\alpha)$. Dalam penelitian ini $\alpha$ yang digunakan sebesar 0,05 ; sebaran data peningkatan motivasi belajar siswa /gain kelas eksperimen mempunyai nilai Sig $=0,000$ dan untuk sebaran data peningkatan motivasi belajar siswa kelas kontrol mempunyai nilai Sig $=0,450$ sehingga sebaran data peningkatan motivasi belajar pada kelas eksperimen tidak berdistribusi normal, sedangkan pada kelas kontrol berdistribusi normal.

Pengujian selanjutnya, karena sebaran data motivasi belajar siswa tersebut terdapat sebaran yang tidak berdistribusi normal, maka digunakan statistika non parametrik, dalam hal ini penulis gunakan uji Mann Whitney. Adapun rumusan hipotesisnya penulis sajikan sebagai berikut:

Ho: Tidak terdapat perbedaan peningkatan motivasi belajar, antara siswa yang pembelajarannya menggunakan program
Powerpoint Ispring dengan siswa yang pembelajarannya tidak menggunakan program Powerpoint Ispring.

Ha: Terdapat perbedaan peningkatan motivasi belajar, antara siswa yang pembelajarannya menggunakan program Powerpoint Ispring dengan siswa yang pembelajarannya tidak menggunakan program Powerpoint Ispring.

Dari hasil pengujian, diperoleh hasil sebagai berikut:

Tabel 9. Uji perbedaan Motivasi Belajar Siswa

\begin{tabular}{lllll}
\hline & Kelas & $\mathrm{N}$ & $\begin{array}{l}\text { Mean } \\
\text { Rank }\end{array}$ & $\begin{array}{l}\text { Sum of } \\
\text { Ranks }\end{array}$ \\
\hline gain_moti & Eksperimen & 36 & 43,06 & 1550,00 \\
vasi & Kontrol & 33 & 26,21 & 865,00 \\
& Total & 69 & & \\
\hline
\end{tabular}

Test Statistics ${ }^{a}$

\begin{tabular}{ll}
\hline & Gain_motivasi \\
\hline Mann-Whitney U & 304,000 \\
Z & $-3,487$ \\
Asymp. Sig. (2-tailed) & 0,000 \\
\hline a. $\quad$ Grouping Variable: Kelas
\end{tabular}

Dari pengujian tersebut, diperoleh ratarata ranking/mean rank dari kelas eksperimen dan kelas kontrol berturut-turut 43,06 dan 26,21. Hasil pengujian dengan uji Mann Whitney U diperoleh nilai sebesar 304,000 dengan nilai $\mathrm{z}$ sebesar -3,487 serta nilai Asymp. Sig. (2-tailed) sebesar 0,000. Adapun kriteria pengujian hipotesisnya adalah, jika nilai Asymp. Sig. (2tailed) lebih kecil dari $\alpha$ maka Ha diterima atau Ho ditolak. Karena pada pengujian ini nilai Asymp. Sig. (2-tailed) $=0,000$ lebih kecil dari $\alpha=$ 0,05 maka Ha diterima, sehingga dapat disimpulkan bahwa: Terdapat perbedaan peningkatan motivasi belajar, antara siswa yang pembelajarannya menggunakan program Powerpoint Ispring dengan siswa yang pembelajarannya tidak menggunakan program Powerpoint Ispring. Dalam hal ini peningkatan motivasi belajar siswa yang pembelajarannya menggunakan program Powerpoint Ispring lebih baik daripada motivasi belajar siswa yang pembelajarannya tidak menggunakan program Powerpoint Ispring.

\section{PEMBAHASAN HASIL PENELITIAN}

Berdasarkan hasil pretes dan postes yang telah disajikan di atas khususnya pada kelas eksperimen, ada beberapa temuan yang akan peneliti kemukakan, yaitu jika melihat rata-rata kelas, pada nilai pretes kelas eksperimen 
mendapatkan skor 27,64 dan simpangan bakunya 12,187. Skor tersebut bukan merupakan skor yang baik karena masih jauh berada di bawah Kriteria Ketuntasan Minimum (KKM) pelajaran Fisika kelas VII materi gerak lurus yaitu nilainya 65 atau skornya 49 dari skor ideal 75. Sementara dalam hasil tes penelitian (pretes) kelas eksperimen ini memperlihatkan bahwa nilai ratarata kelasnya belum mencapai KKM.

Setelah kelas eksperimen diberi perlakuan, yaitu pembelajaran dengan menggunakan program Powerpoint Ispring, ternyata siswa begitu bersemangat dan merasa senang saat proses pembelajaran (Mawardi, E. Effendi, \& $\mathrm{H}$. Effendi, 2017). Selain itu menggiring pada antusisme dan kefokusan belajar sehingga menghasilkan adanya peningkatan pemahaman belajar. Hal ini dapat peneliti lihat berdasarkan pada hasil nilai postes yang telah diberikan. Terjadi peningkatan nilai rata-rata kelas yang signifikan. Untuk kelas eksperimen dari skor sebelumnya 27,64 dengan simpangan bakunya 12,187 berubah meningkat rata-ratanya menjadi 52,61 dengan simpangan bakunya 9,219. Sementara nilai rata-rata pada kelas kontrol, dari skor sebelumnya 27,52 dengan simpangan baku 12,787 berubah menjadi 42,12 dengan simpangan bakunya 10,562.

Penggunaan media pembelajaran seperti halnya Program Aplikasi Microsoft Powerpoint Ispring merupakan sebuah software yang dibuat dan dikembangkan oleh perusahaan Microsoft, dan merupakan salah satu program berbasis multimedia. Didalam komputer, biasanya program ini sudah dikelompokkan dalam program Microsoft Office. Program ini dirancang khusus untuk menyampaikan presentasi, baik yang diselenggarakan oleh perusahaan, pemerintahan, pendidikan, maupun perorangan, dengan berbagai fitur menu yang mampu menjadikannya sebagai media komunikasi yang menarik.

Kemajuan teknologi pembelajaran banyak menghasilkan produk yang bermanfaat bagi penunjang keberhasilan ketercapaian tujuan pembelajaran (Elfizon, Muskhir \& Candra, 2017). Salah satu produk teknologi pembelajaran yaitu Microsoft office PowerPoint yang telah diinsert menu ISpring Presenter. Dengan menggunakan multimedia PowerPoint Ispring siswa lebih termotivasi dan mampu meningkatkan kualitas belajarnya. Dengan demikian maka penggunakan multimedia PowerPoint Ispring diyakini bisa membuat siswa antusias dalam belajar di kelas maupun belajar di rumah. Dengan adanya multimedia tersebut diharapkan guru juga merasa terbantu dalam meminimalisasi tenaga dalam peragaan praktik Fisika (Effendi, Soenarto \& Sofyan, 2015).

Penggunaan program PowerPoint Ispring sangat berpengaruh terhadap motivasi belajar siswa. Motivasi berhubungan dengan perhatian terhadap suatu objek yang disertai dengan keinginan untuk mengetahui dan mempelajarinya maupun membuktikan lebih lanjut. Untuk meningkatkan motivasi belajar harus ditunjang oleh penggunaan media pembelajaran yang tepat dan menarik perhatian siswa (Effendi \& Hendriyani, 2016). Pembelajaran merupakan suatu peristiwa belajar. Disamping menggunakan pikiran, dalam belajar juga memerlukan hati yakni motivasi belajar. Motivasi belajar mempengaruhi kemauan belajar, jika motivasi belajar rendah maka kemauan belajar akan rendah, sebab kemauan berhubungan dengan hati, dan hati berkaitan dengan menerima atau menolak sesuatu.

Teori belajar menyimpulkan bahwa motivasi belajar salah satu indikator untuk mencapai hasil belajar. Pemahaman materi yang tuntas agar menghasilkan hasil belajar itu membutuhkan motivasi belajar yang tinggi. Dengan motivasi ia akan belajar dengan sungguh-sungguh (Bernard, 2002). Dengan motivasi ia akan berusaha mencari buku-buku atau sumber-sumber lain yang berkaitan dengan materi pelajaran khususnya pelajaran Fisika.

Tentang pentingnya motivasi ini dalam pembelajaran, sesuai dengan apa yang dikemukakan Surya (2013) bahwa:

Motif merupakan suatu penggerak yang ditimbulkan dan mendorong perilaku untuk mencapai tujuan. Individu harus melakukan pemilihan motif atau tujuan agar mampu mewujudkan perilaku secara efektif.

Dalam situasi itu individu harus melakukan berbagai pertimbangan agar mampu mengambil keputusan menetapkan perilaku yang akan diwujudkan. Berdasarkan beberapa teori pembelajaran tersebut menunjukkan bahwa sukses tidaknya transfer of knowledge atau pemindahan ilmu pengetahuan antara guru dengan siswa di kelas VII SMPN 2 Tarogong Kidul Garut sangat tergantung dengan media pembelajaran yang digunakan dan cara penyampaian guru (Harandi, 2015). Dalam hal ini dengan adanya teknologi untuk penyampaian bahan ajar yakni menggunakan media dengan program powerpoint Ispring untuk pembelajaran fisika materi gerak lurus di lokasi penelitian (Krismadinata, E. Elfizon \& T. Santika, 2019).

Berdasarkan pengujian perbedaan peningkatan pemahaman konsep gerak lurus pada kelas eksperimen dan kelas kontrol, 
diperoleh hasil bahwa terdapat perbedaan peningkatan pemahaman konsep gerak lurus, antara siswa yang pembelajarannya menggunakan program Powerpoint Ispring dengan siswa yang pembelajarannya tidak menggunakan program Powerpoint Ispring. Dalam hal ini peningkatan pemahaman konsep gerak lurus pada kelas eksperimen lebih baik daripada peningkatan pemahaman konsep gerak lurus pada kelas kontrol. Seperti yang diungkapkan oleh Surya (2013) bahwa: Motif dan motivasi merupakan perilaku konatif sebagai sumber dinamika yang menentukan kualitas kekuatan perilaku. Sebagai makhluk hidup, kelahiran manusia ke alam dunia membawa amanat untuk senantiasa mempertahankan kelangsungan hidup. Untuk itu, semua makhluk hidup (termasuk manusia) dibekali satu sumber dinamika hidup yang berupa prinsip mekanisme homeostatis yaitu prinsip menjaga keseimbangan. Prinsip ini merupakan sumber terjadinya satu dinamika yang mendorong individu berperilaku.

Minat dan motivasi dalam belajar mempunyai hubungan yang erat sekali. Seseorangyang menaruh minat yang tinggi pada mata pelajaran tertentu, biasanya cenderung untuk memperhatikan dan termotivasi terhadap mata pelajaran tersebut (Patmanthara \& Machfud, 2010). Sebaliknya, bila minat dan motivasi belajar rendah maka perhatian siswa terhadap materi yangsedang diajarkan akan sangat berkurang (Megawati, 2016).

Jika hal ini terjadi berlarut-larut dan terusmenerus tanpa adanya upaya seorang pendidik untuk membangkitkannya maka bisa jadi siswa tidak akan pernah memahami dan menaruh perhatian terhadap materi pelajaran. Berdasarkan pengujian perbedaan peningkatan motivasi belajar siswa pada kelas eksperimen dan kelas kontrol, diperoleh hasil bahwa terdapat perbedaan peningkatan motivasi belajar, antara siswa yang pembelajarannya menggunakan program Powerpoint Ispring dengan siswa yang pembelajarannya tidak menggunakan program Powerpoint Ispring (Bustami, O. Candra, \& M. Muskhir, 2018). Dalam hal ini peningkatan motivasi belajar pada kelas eksperimen lebih baik dari pada peningkatan motivasi belajar pada kelas kontrol.

\section{SIMPULAN}

Berdasarkan rumusan masalah, tujuan penelitian dan hasil pembahasan, maka peneliti menyimpulkan dan merekomendasikan hal-hal berikut: (1) Peningkatan pemahaman konsep gerak lurus pada siswa yang pembelajarannya menggunakan program Powerpoint Ispring termasuk dalam kategori sedang dan tinggi. Sementara pada siswa yang pembelajarannya tidak menggunakan program Powerpoint Ispring tidak mengalami peningkatan yang signifikan, yaitu kategori rendah dan sedang. (2) Peningkatan motivasi belajar pada siswa yang pembelajarannya menggunakan program Powerpoint Ispring termasuk dalam kategori sedang dan tinggi. Peningkatan motivasi belajar pada siswa yang pembelajarannya tidak menggunakan program Powerpoint Ispring tergolong kategori rendah dan sedang. (3) Terdapat perbedaan peningkatan pemahaman konsep gerak lurus antara siswa yang pembelajarannya menggunakan program Powerpoint Ispring dengan siswa yang pembelajarannya tidak menggunakan program Powerpoint Ispring. Dalam hal ini peningkatan pemahaman konsep gerak lurus pada siswa yang pembelajarannya menggunakan program Powerpoint Ispring lebih baik dari pada siswa yang pembelajarannya tidak menggunakan program Powerpoint Ispring. (4) Terdapat perbedaan peningkatan motivasi belajar siswa antara siswa yang pembelajarannya menggunakan program Powerpoint Ispring dengan siswa yang pembelajarannya tidak menggunakan program Powerpoint Ispring. Dalam hal ini peningkatan motivasi belajar siswa yang pembelajarannya menggunakan program Powerpoint Ispring lebih baik dari pada peningkatan motivasi belajar siswa yang pembelajarannya tidak menggunakan program Powerpoint Ispring.

\section{UCAPAN TERIMAKASIH}

Tentunya rasa syukur terucap kepada Tuhan Yang Maha Esa atas terselesaikannya penelitian ini. Selanjutnya ucapan terima kasih dan rasa kebanggaan yang besar ditujukan kepada Kepala Sekolah SMP Negeri 2 Tarongong Kidul Garut telah memberikan ijin untuk melaksanakan penelitian. Tidak lupa pula ucapan terimakasih kepada tim pengelola jurnal Edu Komputika Universitas Negeri Semarang atas kesempatan yang diberikan kepada penulis dalam jurnal Edu Komputika edisi 2019.

\section{DAFTAR PUSTAKA}

Patmanthara \& Machfud. (2010). Pengaruh Penggunaan Media Multisimulasi dan Sikap Siswa terhadap Hasil Belajar Konsep Elektronika Digital, Jurnal Teknodik. Vol II.

\footnotetext{
Hernawati. (2011). Modul Pelatihan Ispring Presenter. Terdapat dalam: http://staff.uny.ac.id/sites/default/files/ pengabdian/kuswari-hernawati-
} 
ssimkom/modul-ispring-presenter.pdf. tanggal akses: 17 Mei 2019.

Bernard, M. (2002). Effective Teaching, Principles and Practice. London: Foresman and Company.

Darmawan, D. (2013). Metode Penelitian Kuantitatif. Bandung: Rosdakarya.

Gumawang. (2005). Belajar Mandiri Microsoft Office PowerPoint 2007. Jakarta: Gaung Persada Press.

Iriyanto, S. Y. (2008). Ilmu Pengetahuan Alam. Jakarta: Pusat Pembukuan Depdiknas.

Bustami, O. Candra, \& M. Muskhir. (2018). Penerapan Strategi Training Within Industry Sebagai Upaya Meningkatan Motivasi Perkuliahan. INVOTEK J. Inov. Vokasional dan Teknol., vol. 18, no. 2, pp. 55-64.

Warsita. (2008). Media Pendidikan. Jakarta: Raja Grafindo Persada.

Sugiyono. (2012). Metode Penelitian Kuantitatif, Kualitatif, dan $R \& D$. Bandung: Alfabeta.

Sundayana, R. (2010). Statistika Penelitian Pendidikan. STKIP Garut Press: Garut.

Surya, M. (2013). Psikologi Pembelajaran dan Pengajaran. Bandung: Pustaka Bani Quraisi.

Mawardi, E. Effendi, \& H. Effendi. (2017). The role of locus control and learning styles in the development of the blended learning model at PSU. Int. J. GEOMATE, vol. 13, no. 7, pp. 75-80.

Harandi. (2015). Effects of e-learning on Students' Motivation. Procedia - Soc. Behav. Sci.

Sugiyono. (2016). Metode Penelitian Pendidikan (Kuantitatif Kualitatif dan R \& D). Alfabeta: Bandung.

Suprihatiningrum. (2016). Strategi pembelajaran teori \& aplikasi. Yogyakarta: ArRuzzMedia.

Effendi, Soenarto \& Sofyan. (2015). The Effectiveness of Web-Based Interactive Blended Learning Model in Electrical Engineering Courses. Res. Eval. Educ., vol. 1, no. 2, pp. 175-185.
Krismadinata, E. Elfizon \& T. Santika. (2019). Developing Interactive Learning Multimedia on Basic Electrical Measurement Course. vol. 299, no. Ictvet 2018, pp. 305-308.

Effendi \& Hendriyani. (2016). PENGEMBANGAN MODEL BLENDED LEARNING INTERAKTIF DENGAN PROSEDUR BORG AND GALL. in 2nd International Seminar on Education, pp. 6270. 7-18.

Megawati. (2016). Pengembangan Multimedia Interaktif Berbasis Prezi untuk Siswa Kelas XI IPA pada Materi Struktur dan Fungsi Sel sebagai Unit Terkecil Kehidupan. Universitas Negeri Padang.

Elfizon, Muskhir \& Candra. (2017). Pengembangan Media Trainer Elektronika Dalam Pembelajaran Teknik Elektronika Pada Pendidikan Vokasi Teknik Elektro. Fakultas Teknik Universitas Negeri Padang. 